\title{
Equilibrium
}

Quarterly Journal of Economics and Economic Policy

VOLUME 9 ISSUE 1, 2014

p-ISSN 1689-765X, e-ISSN 2353-3293

www.economic-policy.pl

Dziemianowicz R. (2014), Independent Fiscal Institutions as a Tool of Fiscal Governance, "Equilibrium. Quarterly Journal of Economics and Economic Policy", Volume 9, Issue 1, pp. 59-70, DOI: http://dx.doi.org/10.12775/EQUIL.2014.004

\section{Independent Fiscal Institutions as a Tool of Fiscal Governance}

JEL Classification: $H 61, H 62, H 63$

Keywords: fiscal policy, fiscal discipline, fiscal council, fiscal transparency

\begin{abstract}
The recent economic crisis, one of the symptoms of which is a sudden increase of public debt in the majority of OECD countries, again made the government and the society aware of the necessity for conducting transparent, but also responsible fiscal policy. Creating a framework of the fiscal discipline responsible fiscal policy started to be perceived as an essential condition of effective governance leading to reduce budget deficit and public debt. The independent fiscal institutions may be included into regulations supporting public finance management. Their fundamental aim is to reduce the related risk of conducting the irresponsible fiscal policy, monitoring it, controlling deficit and assessing long-term effects of government action in this area. The purpose of this article is to present independent fiscal institutions and evaluate their usefulness in enhancing the effectiveness of the fiscal policy and stabilizing public finance. Experiences of the EU and OECD countries were used in the analysis.
\end{abstract}

(C) Copyright Institute of Economic Research \& Polish Economic Society Branch in Torun Date of submission: February 26 , 2013; date of acceptance: November 18, 2013

*Contact: r.dziemianowicz@uwb.edu.pl, University in Bialystok, Faculty of Economics and Management, ul. Warszawska 63, 15-062 Białystok, Poland 


\section{Introduction}

The last economic crisis, one of the symptoms of which is a sudden increase of budget deficit, and consequently also public debt in most EU countries (and more broadly, this also applies to any developed economy), again reminded both those in power and the public about the need for a transparent, but also a responsible fiscal policy. The threat to the stability of the public finance system increased interest in regulations strengthening the budgetary surveillance, increasing the discipline of public finances, as well as supporting their consolidation. Responsible fiscal policy creating frameworks of the fiscal discipline started to be seen as an important condition for effective governance, leading to a reduction in the budget deficit and public debt.

When searching for institutional solutions concerning fiscal policy which would ensure the stability of the budgetary receipts and rationalization of public expenditures, the attention was also paid to the need of its coordination, appearing in the reference books under the term fiscal governance. Undoubtedly, one of the tools supporting fiscal governance are independent fiscal institutions, the main objective of which is limiting the risk associated with irresponsible fiscal policy, especially its monitoring, control of deficit and evaluation of the long-term results of the actions taken by the government in this regard.

The aim of this article is to present a typology and scope of actions of independent fiscal agencies as well as the evaluation of their usefulness in strengthening fiscal policy, including the stabilization of public finances. The study was developed basing on literature studies. The analysis also used experience of the EU and OECD countries.

\section{Fiscal governance models - theoretical aspect}

The starting point of the institutional approach to public expenditure planning is identification of the externalities arising from the fact that public funds are usually targeted at specific social groups, although they are financed from general tax revenues, to the creation of which all taxpayers contribute. The result of the mismatch (conflict) between those who pay and those who benefit from individual public policies is that people opting for financing such policies tend to recognize their full benefits, however only part of the social costs is spread evenly over the whole of society (Hallerberg et al. 2005, p. 338). 
The problem of externalities results in excessive deficits and public debt. The essence of the problem is an externality consisting in that the common pool of tax revenues is used for the implementation of policy programs aimed at small groups of society (Hallerberg, von Hagen 2006, p. 7). It may therefore be concluded that the problem of excessive public expenditures and deficits is a result of a failure in coordination of the fiscal policy (organization of the budget process).

The source of the current crisis of public debt is, to a large extent, an expansionary fiscal policy, resulting from the tendency of governments to "deficit bias", implemented in the so called good times, being mainly the effect of discretionary actions and information asymmetry (at the governing - voters level) (wider: Alesina, Perotti 1995). The researches show that in the countries with high deficit greater part of public expenditure is devoted to meeting the needs of narrow interest groups, whereas the pool of prodevelopment expenditures is reduced. E.g. In the nineties, 23 developed countries with a high deficit reached approx. one-eighth worse results in terms of economic growth (and not only) than the countries with a balanced budget (Czyżewicz, Rzońca 2011, p. 9). The question then arises of how to discipline the governing and prevent them e.g. from increasing public expenditures in the period of downturn in the economy, and thus limit the exercise of activities which are expansive (pro-cyclical) in nature, and which consequently lead to an increase in the budget deficit, but also a deterioration in the structure of public expenditures. Assuming that the problem of excessive public expenditures and deficits is a result of the failure in "managing" the fiscal policy (organization of the budget process), to counteract this phenomenon one should first of all implement the appropriate model of its coordination, i.e. the proper fiscal governance model.

Fiscal governance ${ }^{1}$ - understood as coordination of fiscal policy, is covered by the broadly defined concept of public governance, which was established on the basis of public sector reforms and an attempt to introduce the governance methods applicable in the private sector to the public sector. In objective meaning, fiscal governance is defined as rules, regulations and procedures that affect the way fiscal policy is planned, approved, conducted and monitored. Fiscal governance pursues the following objectives:

- counteracting the conduct of the unsustainable fiscal policy, striving to achieve reasonable budget indicators (e.g., deficit and public debt in relation to GDP);

- reducing cyclicity of fiscal policy (ensuring its stability);

${ }^{1}$ More on the concept of fiscal governance in the light of the theory of public finance (Dziemianowicz, Kargol-Wasiluk 2012, pp. 65-76). 
- increasing the efficiency of public spending;

- increasing transparency of fiscal policy.

These objectives may be achieved by reducing discretionary behavior of decision-makers and promoting the more long-term oriented budgetary planning. Fiscal governance may also support efficient use of public resources by monitoring of public spending programs and linking them with sources of allocation (Dziemianowicz, Kargol-Wasiluk 2012, pp. 65-76).

There are two basic institutional approaches to the design of fiscal governance: the delegation model and the contract model, assuming the centralization of the budget process ${ }^{2}$ (Hallerberg, von Hagen 2006, pp. 7-9). According to a study conducted by Hallerberg and Hagen, in the budget process we deal with the "fiscal entrepreneur", the role of whom is to design a budget and ensure that all remaining actors of the process follow the established limits. This fiscal entrepreneur is usually the minister of finance, who should have effective tools for the monitoring and use of sanctions for noncompliance with established rules by the entities ruling the remaining resorts (Hallerberg, von Hagen 2006, p. 10).

The next model is a contract model, in which all members of the government establish common fiscal targets. Thus, the focus is on the negotiation mechanism being a tool for identification of the externalities and on the need to design fiscal targets which will be of binding nature. The model in question assumes a more egalitarian distribution of strategic powers in the government (Hallerberg, von Hagen 2006, p. 12) .

It should be clearly emphasized that without sufficient institutionalization of the widely understood budget process, one cannot speak about efficient functioning of the public finance sector. And this applies to both the first and the second fiscal governance model. At the same time, in order to allow the fiscal policy to fulfill the stabilization function, it should be anti-cyclical, impervious to political pressure, allowing efficient response to changes in the real sphere (Gajewski, Skiba 2010, p. 10). The condition for the sodefined fiscal policy is primarily a high fiscal discipline, regardless of the electoral cycle and economic fluctuations. There are plenty of theoretical and empirical evidences in the reference books showing that very important in the maintenance of the fiscal discipline will be institutions managing the budget process which may determine the country fiscal actions, but also those controlling the actions of the governing within this scope. This is primarily about a responsible fiscal policy, budgeting, budget procedure and

\footnotetext{
${ }^{2}$ In article, the expansive interpretation was adopted - the so called fiscal governance, treating it as the method of coordination of fiscal policy, i.e. in the sphere of public finance.

${ }^{3}$ The authors of the study indicate that selection of the model will depend on the prevailing balance of power in the political arena.
} 
budget implementation procedure, fiscal rules as well as monitoring and assessment of these actions.

The established rules of conduct within the frameworks of the implemented responsible fiscal policy have a significant impact on all the participants of the budget process, regulate the information flow and consequently determine the results of the whole budget process (Hallerberg et al. 2005, p. 338). It should, however, be emphasized that the mere establishment of fiscal rules, budget procedures, even when they are well designed, may be insufficient. The best example is the EU's Stability and Growth Pact, in which the mechanism of strengthening the fiscal discipline in the EU countries proved to be insufficient. The reference books more and more often indicate that the fiscal rules should be strengthened by independent fiscal agencies which will review the fiscal policy, take care of its transparency, prepare forecasts, as well as inform the public about the activities of politicians in this regard.

\section{Typology and scope of tasks of independent fiscal institutions}

One of the tools of the responsible fiscal policy are independent fiscal agencies modeled on the boards of monetary policy, giving opinion on and supporting the fiscal policy implemented by the government. The rationale for their creation is a need to reduce the high budget deficit, the desire to reduce the impact of the so-called election cycle on the politicians' decisions and to improve the quality of fiscal policy, in particular to restrict its discretion and pro-cyclicality, as well as to increase transparency.

Fiscal agencies may be very different depending on the scope of responsibilities and powers. Debrun identifies two theoretical models of independent fiscal bodies differing primarily in terms of scope of tasks and the level of powers (Hagemann 2010, pp. 8-11), namely (Figure1):

- Independent Fiscal Authorities - institutions which set annual targets for the country budget balance and the level of public debt or specify fiscal rules, adjust the level of taxes and public expenditures;

- Fiscal Councils - institutions the task of which is to influence the form of fiscal policy through independent analyses, forecasts and advisory. 
Figure 1. Taxonomy of Fiscal Agencies

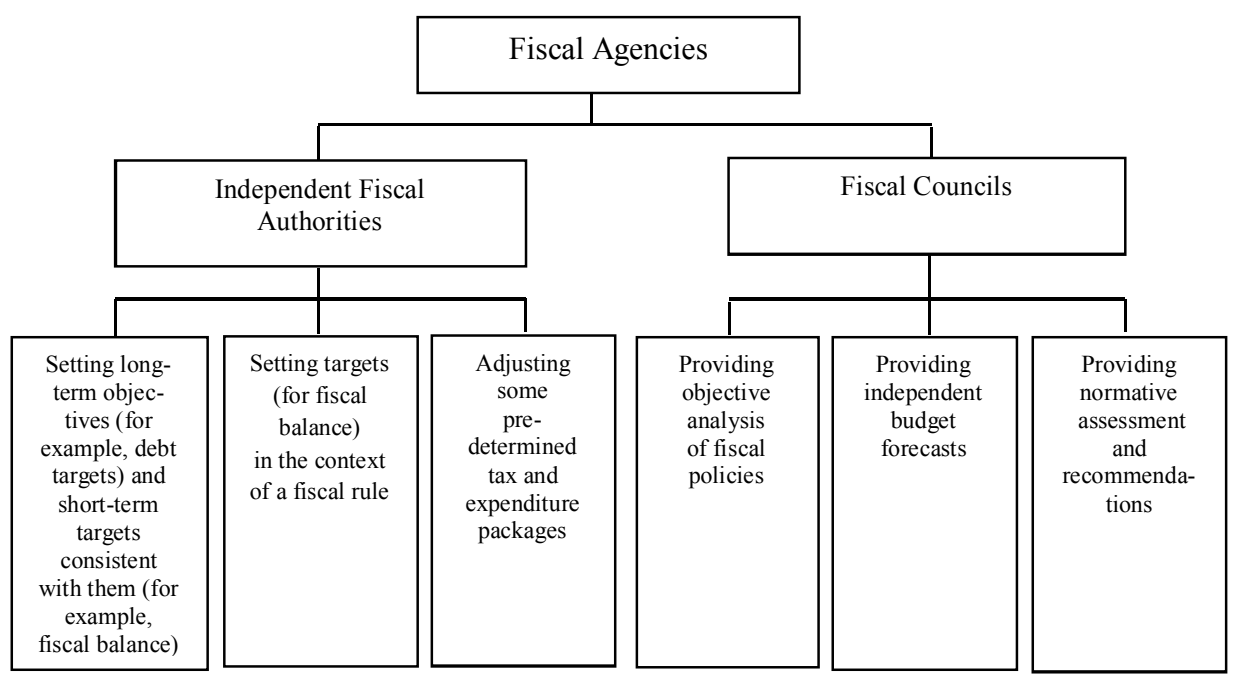

Source: Debrun (2009, p. 57).

In the opinion of Alesina and Tabellini (Alesina, Tabellini 2007, pp. 169179), full delegation of mandate to a "bureaucrat" with which we deal in case of Independent Fiscal Authorities is a good and safe solution when the public preferences are fully recognized and stable. In case of fiscal policy, as opposed to monetary policy, there are, however, too many variables, and therefore the transfer of full responsibility, e.g. for the budget balance of such independent institution is rather unjustified and undesirable (Moździerz 2012, p. 80).

Pursuant to the definition of the European Commission, independent fiscal institutions are defined as independent public entities, other than the central bank, the government or parliament, which prepare macroeconomic forecasts for the budget, monitor the fiscal performance and (or) advise the government on matters of fiscal policy. These institutions function independently of the fiscal authorities, however, are publicly funded (Independent 2013).

Depending on their powers, independent fiscal bodies may also be classified as institutions with the following nature (Gołębiowski 2010, pp. 3-4):

- very soft - opinion-making role, preparation of independent and facultative expert opinions (e.g. German Council of Academic Experts in Germany, The Fiscal System Council in Japan, Korea's National Assembly Budget Office in Korea);

- soft - advisory, prognostic and opinion-making role (e.g. High Council of Finance in Belgium, Danish Economic Council in Denmark, the Netherlands Netherlands Bureau for Economic Policy Analysis in the Nether- 
lands, or The Swedish Fiscal Policy Council established in August 2007 in Sweden).

- hard - every year, it determines the level of the budget balance and the expected level of public debt which constitutes the goal of the budget process implemented by the government (currently, there are no institutions with such scope of powers implemented in EU, however, discussions are held over their appointment).

The tasks of the independent fiscal institutions defined in such way, depending on the scope of their powers, include primarily (Gajewski 2010, p. 90; Calmfors 2011, p. 15):

- public finance assessment, ex-post analysis of fiscal policy and its macroeconomic context (e.g. Sweden), the ex-ante evaluation of fiscal policy (e.g. the UK), the analysis of long-term sustainability of fiscal policy (e.g. the Netherlands, USA);

- development of independent, objective, long-term macroeconomic forecasts for different variants of fiscal policy (e.g. the Netherlands, Denmark, United Kingdom);

- calculation of costs of various government projects (e.g. USA, the Netherlands, Canada);

- formulating recommendations for the government (only certain functioning fiscal institutions have such powers).

It can be concluded that the main objective of these institutions is to reduce the risk associated with irresponsible fiscal policy, especially its monitoring, control of deficit and evaluation of the long-term results of the government's actions within this scope. Appointment of an independent fiscal council does not mean, however, that the budgetary discipline will be automatically improved. According to Debrun, Hauner and Kumar (Gajewski 2010, p. 94), the effectiveness of independent fiscal bodies depends on:

- defining the powers which should clearly reflect a broad social and political consensus;

- including the institutions into the budgeting process, especially regarding the inclusion of its evaluations (e.g. taking into consideration the council opinions in the Parliament's work on the budget);

- legal empowerment of institutions' position in the process of creating the budget, allowing a stronger influence on government decisions.

However, in the opinion of Calmfors, the efficiency of such institutions depends on (Calmfors 2011, p. 19):

- degree of independence - an institution should be fully independent, e.g. as the monetary policy councils, it should have a guaranteed long-term budget that will reduce the possibility of influencing its long-term and irreversible decisions and non-renewable nominations reduce the risk of in- 
fluencing the decisions of individual members, it should not be an institution subordinated to the Government (ambiguous sentence in the original - translator);

- composition - members should be appointed from among scientists, experts in the field of public finance, financial analysts, possibly expoliticians; the composition should be varied;

- ability to influence - the relevant statutory powers, in the long run, it is ensured by the impartiality and quality of analyses.

Creation of independent fiscal councils is particularly beneficial in the countries characterized with high degree of decentralization. Under such conditions, the council coordinates the actions of central and regional authorities in the area of fiscal policy, and often performs the role of a specific arbitrator (Moździerz 2012, p. 81).

\section{Role of independent fiscal agencies - international experience}

Interest in the creation of independent fiscal agencies during the crisis period increases. Not only the European Commission, but also IMF and OECD are encouraged to establish such institutions. Therefore, independent fiscal agencies already function in many countries, and their number has been increasing steadily in recent years, although they are still an exception rather than the rule. Independent fiscal agencies should not be confused with the institutions auditing the public sector, which already have a long tradition and operate in approximately 150 countries. They are also independent, yet their tasks mainly include ex-post control of the units of public sector and they do not deal, as opposed to the fiscal agencies, with ex-ante analyses and assessment of the adopted macroeconomic assumptions.

The first independent fiscal agency ${ }^{4}$ in Europe was established after World War II, in 1945, in the Netherlands under the name Central Planning Bureau $(\mathrm{CPB})^{5}$. Similar body under the name Congressional Budget Office (CBO) has been functioning in the USA since 1975; its tasks include development of objective and independent macroeconomic and budget analyses for the Congress. Since 2007, such institutions have been created in Sweden (2007), Hungary (2009), Slovenia (2009), Romania (2010). Office for Budg-

\footnotetext{
${ }^{4}$ In the literature we also find information that the first institution of this type in Europe was High Council of Finance (HCF) in Belgium, which was established in 1936. However, HCF has been functioning with the extended powers since 1989.

${ }^{5}$ Although CPB started its functioning in 1945, just after World War II, it was formally established under the Act dated $21^{\text {st }}$ April 1947. The name - Central Planning Bureau - may confuse, as in fact CPB has never prepared the guidelines for the Dutch economy.
} 
et Responsibility (OBR) patterned on American CBO was established in Great Britain in 2011. Fiscal Council was established in Portugal in 2012. Outside Europe, independent fiscal agencies function, among others, also in Australia, Japan, Chile, Canada, Mexico, Korea and Serbia (Moździerz 2012, p. 82).

Independent fiscal agencies functioning in particular countries vary considerably within the scope of their powers (Table 1 ). When analyzing the scope of powers of fiscal councils appointed in EU in the period of the last crisis, i.e. in years 2007-2011, one can say that one of the strongest mandates was received in 2009 by the institution functioning in Hungary (Fiscal Council of Hungary), the tasks of which included: development of analyzes of fiscal policy, supply of macroeconomic forecasts and regulatory assessments. Unfortunately, due to the political changes that took place in 2010, its powers were significantly limited ${ }^{6}$ (Hagemann 2011, p. 86). British Office for Budget Responsibility has quite broad powers - its tasks include preparation of macroeconomic forecasts and assessment of functioning tax regulations and stability of the public debt.

Normative assessment and recommendations concerning fiscal policy may also be provided by Swedish Fiscal Policy Council, which however does not have powers to prepare forecasts. Fiscal agency functioning in Slovenia has only consultative powers concerning fiscal policy. However, an independent fiscal institution Consiliul Fiscal in Romania gives opinions and recommendations concerning fiscal strategy, annual Budgetary Act, implementation of the budget and major legislative initiatives that may possibly have an impact on the level of budget income and expenditures (Moździerz 2012 , p. 84). None of the functioning fiscal agencies has determining powers. They are advisory in nature only in Sweden and Belgium. Moreover, in Belgium, the government is almost obliged to adopt the macroeconomic forecasts of the High Council of Finance.

${ }^{6}$ An additional pretext for statutory limitation of the functioning of the fiscal council in Hungary was the council's issuing of the critical medium-term assessment of the budget strategy of new government (included in the Budgetary Act for year 2011) (wider Hagemann 2011). 
Table 1. Structure and functions of selected fiscal agencies

\begin{tabular}{|l|l|l|c|c|c|c|}
\hline \multirow{2}{*}{$\begin{array}{l}\text { Country and year } \\
\text { of establishment }\end{array}$} & \multirow{2}{*}{$\begin{array}{c}\text { Management } \\
\text { (Head) }\end{array}$} & \multicolumn{5}{|c|}{ Functions } \\
\cline { 3 - 7 } & One-person & Monitoring & $\begin{array}{c}\text { Macro- } \\
\text { fiscal }\end{array}$ & $\begin{array}{c}\text { Assessment } \\
\text { of stability }\end{array}$ & $\begin{array}{c}\text { Risk } \\
\text { assessment }\end{array}$ & Forecasts \\
\hline USA 1975 & One-person & of Rules & yes & yes & yes & No \\
\hline $\begin{array}{l}\text { the Netherlands } \\
1945\end{array}$ & Collective & $\begin{array}{l}\text { of Objec- } \\
\text { tives }\end{array}$ & yes & yes & & \\
\hline Belgium 1989 & Collective & of Rules & yes & yes & yes & No \\
\hline Sweden 2007 & One-person & $\begin{array}{l}\text { of Objec- } \\
\text { tives }\end{array}$ & yes & & & \\
\hline Canada 2008 & Collective & of Rules & yes & yes & yes & no \\
\hline Hungary 2009 & Collective & $\begin{array}{l}\text { of Objec- } \\
\text { tives }\end{array}$ & yes & yes & yes & no \\
\hline $\begin{array}{l}\text { Great Britain } \\
2010\end{array}$ & & & & & & \\
\hline
\end{tabular}

Source: own development on the basis of (Kopits 2011).

In most cases, the activity of these institutions is based on the work of the employed workers, e.g. American CBO employs 230 people. However, even here there are exceptions, e.g. Belgian High Council and Swedish Fiscal Policy Council cooperate only with other trusted institutions.

In Poland, as yet, no decision has been made on the establishment of an independent fiscal council, even though in 2012 the project on its establishment was submitted in the Parliament by the SLD Parliamentary Club. Undoubtedly, the establishment of such a council could have an impact on the limitation of the pro-cyclicality of fiscal policy and, which is very important, an increase of its transparency.

It can be concluded that fiscal agencies functioning around the world are very diverse. Depending on the specificity of a given economy, they have various powers and tasks, however, most of them are closer to the fiscal councils model but also here, the scope of powers is diverse. Previous studies indicate that the fiscal councils having wider powers have greater impact on fiscal discipline and improve the quality of fiscal policy. Ultimately, however, their effectiveness depends on the scope of the mandate granted to them, but also on the degree of independence. At the same time, the European Commission's studies show that the budget deficit level in the countries of operation of an independent fiscal agency is significantly lower in comparison to countries without such institutions (Public 2006). 


\section{Conclusions}

Responsible fiscal policy is perceived as a significant condition for effective governance, leading to a reduction in the budget deficit and public debt. One of its tools are undoubtedly independent fiscal agencies supporting the fiscal policy implemented by the government.

Independent fiscal bodies monitoring and assessing this field of operation of the governing are not a new solution. They have been functioning for many years, the example of which may be Dutch Central Planning Bureau or American Congressional Budget Office, although they are still not common. It turns out that politicians are reluctant to delegate part of their mandate to such institutions. Those that have been already established have a model similar to fiscal council which, in contrast to the independent fiscal authorities, has a narrower scope of powers, e.g. without the possibility to establish annual purposes within the scope of budgetary policy. It can be assumed that from the point of view of decision-makers, fiscal council model is probably easier to accept.

During the crisis, the pressure on the establishment of independent fiscal councils which may have at least advisory influence on fiscal policy seems to be natural. Studies confirm that the use of such selected, well "construed" institutions facilitates the implementation of counter-cyclical stabilization policy, and above all disciplines politicians and limits their irresponsible actions in the conduct of fiscal policy. It should however be emphasized that independent fiscal councils, as indicated by analyses of , among others, IMF, will have a significant impact primarily in the institutionally developed economies, where both the government and parliament will take into account the recommendations developed by them.

\section{References}

Alesina A., Perotti R. (1995), Political economy of budget deficits, „Staff Papers International Monetary Fund", Vol. 1., http://dx.doi.org/10.2307/3867338.

Alesina A., Tabellini G. (2007), Bureaucrats or Politicians? Part 1: A Single Policy Task, „American Economic Review”, Vol. 97, No. 1.

Calmfors L. (2011), The Role of Independent Fiscal Policy Institutions, „CESIFO Working Paper" No. 3367, http://papers.ssrn.com/sol3/papers.cfm?abstract_id $=1775797$.

Czyżewicz P., Rzońca A. (2011), Mechanizm oddziaływania deficytu fiskalnego na wzrost gospodarki, „Gospodarka Narodowa”, No. 10.

Debrun X., Hauner D., Kumar M. S. (2009), Independent fiscal agencies, „Journal of Economic Surveys", Vol. 23, No. 1, http://dx.doi.org/10.1111/j.14676419.2008.00556.x. 
Dziemianowicz R., Kargol-Wasiluk A. (2012), Koncepcja fiscal governance w świetle teorii finansów publicznych - wnioski dla Polski [in:] Alińska A., Pietrzak B. (ed.), Stabilność systemu finansowego. Instytucje, instrumenty, uwarunkowania. CeDeWu, Warszawa.

Gajewski P., Skiba L. (2010), Problemy polityki fiskalnej Polski na drodze do strefy euro $w$ kontekście uwarunkowań $i$ doświadczeń innych państw, NBP, Warszawa, http://www.nbp.pl/publikacje/o_euro/reformy_fiskalne.pdf(09.03.2013).

Gołębiowski G. (2010), Rada Polityki Fiskalnej, „Infos”, No 9, http://orka.sejm.gov.pl/WydBAS.nsf/0/DB639B355CB34C48C12577150029468 A/\$file/infos $79 . p d f$.

Hagemann R. (2010), Improving Fiscal Performance Through Fiscal Councils, „OECD Economics Department Working Papers”, No. 829, http://www.oecd. org/eco/surveys/46673013.pdf.

Hagemann R. (2011), How Can Fiscal Councils Strengthen Fiscal Performance? „OECD Journal: Economic Studies”, No.1, http://dx.doi.org/10.1787/eco studies-2011-5kg2d3gx4d5c.

Hallerberg M., Strauch R., von Hagen J. (2005), The design of fiscal rules and forms of governance in European Union Countries, „European Journal of Political”, Vol. 23, No. 2, http://dx.doi.org/10.1016/j.ejpoleco.2006.11.005.

Hallerberg M., von Hagen J. (2006), Organizacja procesu budżetowego w Polsce. Reguly budżetowe a stabilność fiskalna $i$ gospodarcza, Ernst \& Young, Warszawa, http://webapp01.ey.com.pl/EYP/WEB/eycom_download.nsf/reso urces/Organizacja_procesu_budzetowego_pl.pdf/\$FILE/Organizacja_procesu_b udzetowego pl.pdf (10.03.2013).

Hoffman B., Gibson C. (2005), Fiscal Governance and Public Services: Evidence from Tanzania and Zambia, University of California, San Diego, http://irtheoryandpractice.wm.edu/seminar/papers/Fiscal\%20Governance.pdf (12.03.2013).

Independent fiscal institutions in the EU Member States http://ec.europa.eu/ economy_finance/db_indicators/fiscal_governance/independent_institutions/index_ en.htm (12.03.2013).

Kopits G. (2011), Independent Fiscal Institutions: Developing Good Practices, „,OECD Journal on Budgeting”, Vol. 11, No. 3, http://dx.doi.org/10.1787/ budget-11-5kg3pdgcpn 42 .

Moździerz A. (2012), Przestanki powotania rady fiskalnej w Polsce, „Zeszyty Naukowe PTE Kraków", No. 12, http://www.krakow.pte.pl/pliki/zn-pte-nr-12/zn12 mozdzierz.pdf.

Public finances in EMU (2006), „European Economy”, No. 3. http://ec.europa.eu/ economy_finance/publications/publication423_en.pdf (12.03.2013). 